\title{
Impact of dietary and lifestyle choices on menstrual patterns in medical students
}

\author{
Sreelakshmi U.*, V. Tushara Bindu, Subhashini T., K. Saritha
}

Department of Obstetrics and Gynecology, Mallareddy Medical College for Women, Suraram, Hyderabad, Telangana India

Received: 18 February 2019

Accepted: 25 February 2019

*Correspondence:

Dr. Sreelakshmi U,

E-mail: dr.sreelakshmi@yahoo.com

Copyright: (c) the author(s), publisher and licensee Medip Academy. This is an open-access article distributed under the terms of the Creative Commons Attribution Non-Commercial License, which permits unrestricted non-commercial use, distribution, and reproduction in any medium, provided the original work is properly cited.

\begin{abstract}
Background: The aim of the study was to evaluate average age of menarche, the pattern and types of menstrual disorders and their relation with BMI, dietary habits, physical exercise and stress.

Methods: A cross sectional prospective study was conducted on female medical students during the academic year 2018-2019 at Mallareddy medical college for women, Suraram, Hyderabad, India. The various life style factors including BMI, junk food consumption and physical exercise were factored. Prevalence of each different menstrual abnormality were identified and analyzed by Chi-squire test and $\mathrm{p}$ value $<0.005$ was considered as statistically significant.

Results: Study included 255 medical students who had attained menarche without known medical problems. Mean age of menarche was 12.81years. The most frequent menstrual disorders were premenstrual syndrome $192(75 \%)$, dysmenorrhoea $146(57 \%)$, and irregular cycle 97(38\%). Statistically significant association of Body mass index (BMI) related to premenstrual syndrome (PMS) and dysmenorrhoea was reported (both p<0.05). Similarly, statistically significant association of lack of physical activity had greater risk of premenstrual syndrome and dysmenorrhoea (both $\mathrm{p}<0.0001$ ). Unhealthy dietary patterns had statistically significant higher risk for dysmenorrhoea $(\mathrm{p}<0.0001)$.

Conclusions: In conclusion premenstrual symptoms, dysmenorrhoea and menstrual irregularities were more prevalent. Majority of symptoms were stress, pain abdomen, irritability, mood swings. Comprehensive education programs on lifestyle modifications like regular physical activities, promoting healthy eating habits should be emphasised to prevent menstrual abnormalities of young students as early as at school level.
\end{abstract}

Keywords: BMI, Dysmenorrhoea, Menstrual disorders, PMS

\section{INTRODUCTION}

Menstruation is a fundamental physiological phenomenon of normal sexual and reproductive function. Evidence from previous literatures indicates that after menarche third year onwards the episode of interval between bleeding periods is in the range of 21-34 days, with a flow lasting from 3 to 7 days and a mean menstrual blood loss around $35 \mathrm{ml}$ (range 5-80ml).
However, in the abnormal menstrual patterns it might vary in interval, duration of flow and/or quantity of blood flow with different conditions named from amenorrhea, oligomenorrhea, heavy menstrual bleeding, frequent menstrual cycles, irregular cycle, pain and premenstrual symptoms.

These above stated menstrual irregularities encompasses a wide variety of cyclic, recurrent, physical, emotional 
and behavioural symptoms occurring during late luteal phase of menstrual cycle and subsiding with the beginning of menses. ${ }^{1,2}$ Pain perceived before or during menstruation is common symptom know as dysmenorrhoea in women of especially reproductive age usually begins during adolescence with normal pelvic anatomy. ${ }^{3}$ Various studies conducted in students including medical student's show that are at high risk for developing menstrual irregularities probably due to stressful lifestyle, long hours of work, insufficient sleep, irregular food and exercise habits.

Menstrual problems frequently affect the quality of life of young adult women and may indirectly affect on quality of life of family members, social life and economy as well. ${ }^{4}$ Many studies have showed relation between menstrual disorders and life style factors. ${ }^{5,6,7}$

However, early identification and sorting of aetiologies in relation to abnormal menstruation in women's health is mostly neglected by primary health care. ${ }^{8}$ So, early interventions at etiological level like disorders of body mass index (BMI), dietary habits, physical exercise and psychological stress may prevent menstrual disorders. Therefore, to understand menstrual patterns in young medical students conducted a cross-sectional study to evaluate average age of menarche, the pattern and types of menstrual disorders and their relation with BMI, dietary habits, physical exercise and stress.

\section{METHODS}

A cross sectional prospective study was conducted on female medical students during the academic year 20182019 at Mallareddy medical college for women, Suraram, Hyderabad, India. Students willing to participate in the proposed study were explained about the purpose of the study and were given information on the questionnaire after obtaining consent. The questionnaires were selfexplanatory, and students were asked to fill self, from all those who agreed to participate. Students with medical problems associated menstrual abnormalities excluded from this study. Any difficulties in understanding the questionnaire were clarified. Informed consent was obtained from all the participants. The study protocol was evaluated and approved by the Institute Ethics Committee (IEC). Demographic profile information about all the study participants regarding age, social status, religion, dietary habits, and physical exercise were also collected from all the students.

The anthropometric measurements of weight and height are measured and recorded at the study entry and body mass index was calculated. The questionnaires provided to students were included to record details of menstrual history including age at menarche, average length of menstrual cycle, duration of menstrual flow, history of passage of clots during menses, presence of dysmenorrhoea or any preceding symptoms like headache, mood swings and irritability suggesting premenstrual symptoms. Severity of dysmenorrhoea was measured using the pain related scale Visual Analogue Scale (VAS). The questionnaire also evaluated history about the menstrual abnormalities that had severe episodes which warranted to skip the classes and also recorded needing of medication or medical attention if any.

Data related to lifestyle factors were assessed for correlation with menstrual problems experienced by the female medical students. The various life style factors including BMI, junk food consumption and physical exercise were factored. Prevalence of each different menstrual abnormality were identified and analyzed by Chi-squire test. Statistical significance was considered if the differences between each menstrual abnormality was tested and $\mathrm{p}$ value $<0.005$ was considered as statistically significant.

\section{RESULTS}

Study included 255 medical students who had attained menarche with mean age being 20.73 years and mean BMI of 22.77. The characteristics of the students were shown in Table 1.

Table 1: Characteristics of medical students.

\begin{tabular}{|c|c|c|}
\hline Characteristics & $\begin{array}{l}\text { No. of students } \\
(n=255)\end{array}$ & $\%$ \\
\hline \multicolumn{3}{|l|}{ Age (years) } \\
\hline $17-20$ & 101 & 40 \\
\hline $21-23$ & 154 & 60 \\
\hline \multicolumn{3}{|l|}{ BMI } \\
\hline 16-17.9 & 29 & 11 \\
\hline $18-24.9$ & 165 & 65 \\
\hline $25-30$ & 61 & 24 \\
\hline \multicolumn{3}{|l|}{ Diet pattern } \\
\hline Home food/hostel food & 140 & 55 \\
\hline \multicolumn{3}{|c|}{ Frequent junk food intake } \\
\hline 2-3 days/week & 90 & 35 \\
\hline 4-5 days/week & 25 & 10 \\
\hline \multicolumn{3}{|l|}{ Physical activity } \\
\hline 2-3 days/ week & 72 & 28 \\
\hline 4-5days/week & 31 & 12 \\
\hline
\end{tabular}

Mean age of attainment of menarche was 12.81 years. Menstrual pattern and types of menstrual characteristics of the participants were provided in Table 2. Study reported maximum number of participants' attained menarche at the age of 11-13 years (70\%). It was observed that $158(62 \%)$ girls had a regular menstrual cycle history. Menstrual irregularities were reported by $97(38 \%)$ girls. Excessive menstrual flow was reported by $35(14 \%)$ girls. The Majority of the students had duration of the menstrual flow 3-7 days $(85 \%)$. The most frequent menstrual disorders in the students were premenstrual syndrome 192 (75\%), dysmenorrhoea 146 (57\%), and irregular cycle 97 (38\%) (Table 2). 
Table 2: Menstrual pattern in medical students.

\begin{tabular}{|c|c|c|}
\hline Parameter & $\begin{array}{l}\text { No. of } \\
\text { students } \\
(n=255)\end{array}$ & $\%$ \\
\hline \multicolumn{3}{|l|}{ Age of menarche (years) } \\
\hline $9-11$ & 32 & 12 \\
\hline $11-13$ & 178 & 70 \\
\hline $13-15$ & 45 & 18 \\
\hline \multicolumn{3}{|l|}{ Cycle length } \\
\hline $21-35$ & 167 & 66 \\
\hline$<21$ & 36 & 14 \\
\hline$>35$ & 52 & 20 \\
\hline \multicolumn{3}{|l|}{ Cycle regularity } \\
\hline Regular & 158 & 62 \\
\hline Irregular & 97 & 38 \\
\hline \multicolumn{3}{|l|}{ Duration of flow } \\
\hline$<2$ days & 14 & 5 \\
\hline 3-5days & 158 & 62 \\
\hline 5-7days & 58 & 23 \\
\hline$\geq 8$ days & 25 & 10 \\
\hline \multicolumn{3}{|l|}{ Amount of blood loss } \\
\hline Heavy & 35 & 14 \\
\hline Moderate & 206 & 81 \\
\hline Scanty & 14 & 5 \\
\hline \multicolumn{3}{|l|}{ Dysmenorrhoea } \\
\hline No & 109 & 43 \\
\hline Yes & 146 & 57 \\
\hline Grade-1 & 84 & 57 \\
\hline Grade-2 & 52 & 36 \\
\hline Grade-3 & 10 & 7 \\
\hline $\begin{array}{l}\text { Premenstrual syndrome } \\
\text { (PMS) }\end{array}$ & 192 & 75 \\
\hline
\end{tabular}

The results also indicate that students had more than one symptom related to premenstrual syndrome.

Table 3: Prevalence of premenstrual symptoms among medical students.

\begin{tabular}{|c|c|c|}
\hline Premenstrual symptoms & $\begin{array}{l}\text { No. of } \\
\text { students } \\
(n=192)\end{array}$ & $\%$ \\
\hline Stress & 183 & 95 \\
\hline Abdominal pain & 146 & 76 \\
\hline Irritability & 124 & 64 \\
\hline Lack of concentration & 122 & 63 \\
\hline Headache & 102 & 53 \\
\hline Backache & 97 & 50 \\
\hline Mood swings & 86 & 45 \\
\hline $\begin{array}{l}\text { Decreased physical activity and } \\
\text { restrain from work }\end{array}$ & 62 & 32 \\
\hline Breast tenderness & 32 & 16 \\
\hline Nausea, vomiting & 20 & 10 \\
\hline Bowel disturbances & 19 & 10 \\
\hline
\end{tabular}

Women with premenstrual syndrome had higher prevalence of family history of premenstrual syndrome in their sibling's (sisters) and mothers. Majority of the students had stress 183 (95\%) followed by abdominal pain $146(76 \%)$ during menstruation, followed by irritability $(64 \%)$ and lack of concentration $(63 \%)$ mood swings 86 (45\%) during menstruation observed (Table 3). Decreased physical activity and restrain from work during menstruation was reported by 62 (32\%) students. Irregular bowel habits were noticed to an extent of 19 (10\%) students (Table 3).

Statistically significant association of BMI related to premenstrual syndrome and dysmenorrhoea was reported (both $\mathrm{p}<0.05$ ) (Table 4).

Table 4: Association between BMI, premenstrual syndrome and dysmenorrhoea.

\begin{tabular}{|c|c|c|c|c|c|c|c|}
\hline \multirow[t]{2}{*}{ Parameter } & \multicolumn{2}{|c|}{$\begin{array}{l}\text { BMI } \\
(16-17.9) \\
n=29\end{array}$} & \multicolumn{2}{|c|}{$\begin{array}{l}\text { BMI } \\
(18-24.9) \\
n=165\end{array}$} & \multicolumn{2}{|c|}{$\begin{array}{l}\text { BMI } \\
(25-30) \\
n=61\end{array}$} & \multirow[t]{2}{*}{$\begin{array}{l}\text { P- } \\
\text { value }\end{array}$} \\
\hline & Yes & No & Yes & No & Yes & No & \\
\hline $\begin{array}{l}\text { Students with } \\
\text { PMS }(n=192)\end{array}$ & 21 & 8 & 133 & 32 & 38 & 23 & 0.017 \\
\hline $\begin{array}{l}\text { Students with } \\
\text { dysmenorrhoea } \\
(\mathrm{n}=146)\end{array}$ & 19 & 10 & 102 & 63 & 25 & 36 & 0.012 \\
\hline
\end{tabular}

Similarly, statistically significant association of lack of physical activity had greater risk of premenstrual syndrome and dysmenorrhoea (both $\mathrm{p}<0.0001$ ) (Table 5).

Table 5: Association of PMS and dysmenorrhoea with physical activity.

\begin{tabular}{|l|l|l|l|l|l|}
\hline Parameter & $\begin{array}{l}\text { Regular } \\
\text { physical } \\
\text { exercise } \\
\text { (n=103) }\end{array}$ & \multicolumn{3}{l}{$\begin{array}{l}\text { Without } \\
\text { physical } \\
\text { activity } \\
\text { (n=152) }\end{array}$} & p-value \\
\hline & Yes & No & Yes & No & \\
\hline $\begin{array}{l}\text { Students with } \\
\text { premenstrual } \\
\text { syndrome } \\
\text { (n=192) }\end{array}$ & 65 & 38 & 127 & 25 & $<0.0001$ \\
$\begin{array}{l}\text { Students with } \\
\text { dysmenorrhoea } \\
\text { (n=146) }\end{array}$ & 41 & 62 & 105 & 47 & $<0.0001$ \\
\hline
\end{tabular}

Hence, strong association was noted between lack of physical exercise and premenstrual syndrome and dysmenorrhoea.

In addition, the association with unhealthy dietary patterns had statistically significant higher risk for dysmenorrhoea $(\mathrm{p}<0.0001)$ (Table 6).

However, the association with unhealthy dietary patterns did not have significant impact on premenstrual syndrome (Table 6). 
Table 6: Association of PMS and dysmenorrhoea with diet pattern.

\begin{tabular}{|c|c|c|c|c|c|}
\hline \multirow[t]{2}{*}{ Parameter } & \multicolumn{2}{|c|}{$\begin{array}{l}\text { Frequent } \\
\text { junk food } \\
(n=115)\end{array}$} & \multicolumn{2}{|c|}{$\begin{array}{l}\text { Home/hostel } \\
\text { food }(n=140)\end{array}$} & \multirow[t]{2}{*}{ P-value } \\
\hline & Yes & No & Yes & No & \\
\hline $\begin{array}{l}\text { Students with } \\
\text { premenstrual } \\
\text { syndrome } \\
(\mathrm{n}=192)\end{array}$ & 89 & 26 & 103 & 37 & 0.482 \\
\hline $\begin{array}{l}\text { Students with } \\
\text { dysmenorrhoea } \\
(\mathrm{n}=146)\end{array}$ & 81 & 34 & 65 & 75 & $<0.0001$ \\
\hline
\end{tabular}

\section{DISCUSSION}

In developing countries women in reproductive age are significantly affected by menstrual disorders and women are less concern over their menstrual disorders as they are not of threatening conditions. Even though, change in the menstrual patterns in regularity, frequency, cycle length, duration, premenstrual symptoms and dysmenorrhoea in the reproductive age group may affect day to day life in terms of physical, physiological health and psychological well-being. ${ }^{9}$

The mean age of attainment of menarche in the present study was $12.81 \pm 1.22$ years, different studies have shown similar age of attaining menarche: 12.6 \pm 1.32 year (Nirmala J L et al), 12.5 \pm 1.52 years (Singh A et al), $12.67 \pm 1.10$ years (Sthrotriya $C$ et al), $12.4 \pm 1.3$ years (Rigon. F et al), $12.6 \pm 1.0$ years (Begum J et al). ${ }^{10-14}$ Few studies have identified the various factors such as socioeconomic status, nutritional and health status, heredity, environmental conditions, body stature, family size, level of education and psychological well-being have influence on age at onset of menarche. ${ }^{15,16}$

In this present study, it was observed $62 \%$ of participants had regular cycles, whereas $38 \%$ had irregular cycles. While in Mohite and Mohite study and Sujatha et al study reported irregular cycles $26.1 \%$ and $12 \%$ respectively. ${ }^{8,15}$ In present study $81 \%$ of the students had normal amount of menstrual flow, while $5 \%$ had scanty flow and $14 \%$ had heavy blood loss similar to reported in Sujatha et al study with normal flow in $78 \%$, scanty flow in $14 \%$ and heavy flow in $8 \%$ of students. ${ }^{15}$ Above mentioned studies were showing minor differences mainly due to environmental, nutritional and lifestyle factors. In present study, moderate flow was reported with regular cycles, whereas heavy flow was mainly reported who had irregular cycles, these results coincides with Sujatha et al study.

Premenstrual syndrome is a multifactorial syndrome, characterized by manifestation of psychological, physical and behavioral symptoms. The typical symptoms include irritability, lack of concentration, mood swings, depression, stress, anxiety, abdominal bloating, breast tenderness and fatigue. ${ }^{17}$ In this study $75 \%$ had premenstrual symptoms, majority of them had usual stress $(95 \%)$, abdominal pain $(76 \%)$, irritability (64\%) and lack of concentration (63\%), mood swings (45\%) during menstruation. Decreased physical activity and restrain from work during menstruation was reported by $32 \%$ of students. Irregular bowel habits were noticed to an extent of $10 \%$. Singh A et al, reported premenstrual symptoms in $\sim 61 \%$ of students. Kavitha C. study reported $63 \%$ Wasnik VR et al reported $\sim 18 \%$ of students had premenstrual syndrome. ${ }^{11,17,18}$ Variations in prevalence rate of premenstrual symptoms may be due to variations in sample size, methodology, regional variation, study participants selection criteria etc.

Dysmenorrhoea is an important sign of functional disturbance in the hypothalamic-pituitary-ovarian axis. Recently, it has become an important public health problem among the female population. It is characterized by localized pain in the abdominal inferior quadrants. Dysmenorrhoea is classified into 3 grades (Grade- 1, not requiring analgesic; Grade-2, painful, requiring analgesic; Grade-3, painful, not relieved by analgesic). ${ }^{19}$ In present study the prevalence of dysmenorrhoea was $57 \%$, which was comparable to the studies that were reported by Montero P in Moroccan girls, Nair P et al in rural area of East Delhi and Sheila W et al in Madras were 57\%, $63.75 \%$ and $61 \%$, respectively. Agarwal and Agarwal 23 reported high prevalence of dysmenorrhoea (71.96\%) among adolescent girls of Gwalior. ${ }^{20-23}$

Table 7 Provides information regarding severity of dysmenorrhoea. Sujatha et al 15 and Nirmala J L et al were showing severe pain in $6.5 \%$ and $5 \%$ of participants respectively similar to present study $(7 \%) .{ }^{10}$ Satish kumar et al study and Nisreen et al had severe dysmenorrhoea in $66 \%$ and $61 \%$ respectively in contrast to present study. $^{24,25}$

Table 7: Comparison of severity of dysmenorrhoea in different studies.

\begin{tabular}{|l|l|l|l|l|l|}
\hline Dysmenorrhoea severity & $\begin{array}{l}\text { Present study } \\
\text { N=146 }\end{array}$ & $\begin{array}{l}\text { Sujatha et } \\
\text { al }^{15} \mathbf{N}=122\end{array}$ & $\begin{array}{l}\text { Nirmala et al } \\
\mathbf{N}=152\end{array}$ & $\begin{array}{l}\text { Nisreen A et } \\
\mathbf{a l}^{25} \mathbf{N}=154\end{array}$ & $\begin{array}{l}\text { Satish Kumar PK et } \\
\text { al }^{24} \mathbf{N}=78\end{array}$ \\
\hline Grade-1 & $57 \%$ & $55.7 \%$ & $61 \%$ & $18.8 \%$ & $17.8 \%$ \\
\hline Grade-2 & $36 \%$ & $37.7 \%$ & 34 & $19.5 \%$ & $15.6 \%$ \\
\hline Grade-3 & $7 \%$ & $6.5 \%$ & $5 \%$ & $61.6 \%$ & $66.6 \%$ \\
\hline
\end{tabular}


Dysmenorrhoea, premenstrual syndrome and heavy flow were the main reasons for absence from class or college. Most of the students experienced menstrual disorders more commonly around the time of academic assessments confirming the stress induced abnormalities. Previous studies have shown a high prevalence of premenstrual syndrome, dysmenorrhoea and menstrual irregularities among female medical students and are most common causes for college absenteeism, limitation of daily, social and academic activities. ${ }^{26-28}$ Table 8 was providing information about menstrual irregularities and their association with BMI, consumption of junk food and physical exercise in different studies. In present study increase in BMI was significantly associated with premenstrual syndrome and dysmenorrhoea. But, in Rupavani et al, Anandha lakshmi et al, and Sujata et al studies increase in BMI was not significantly associated with dysmenorrhoea. ${ }^{15,29,30}$ Participants those who were consuming junk food on regular basis showed a significant association with dysmenorrhoea and not with premenstrual syndrome in contrast to Rupavani et al, Anandha Lakshmi et al and Sujatha et al studies. ${ }^{30}$

Table 8: Correlation of PMS and dysmenorrhoea with lifestyle and diet pattern comparison with other studies.

\begin{tabular}{|c|c|c|c|c|c|c|}
\hline Parameters & \multicolumn{2}{|l|}{ BMI } & \multicolumn{2}{|l|}{ Junk food } & \multicolumn{2}{|c|}{ Physical exercise } \\
\hline Studies & $\begin{array}{l}\text { Premenstrual } \\
\text { syndrome }\end{array}$ & Dysmenorrhoea & $\begin{array}{l}\text { Premenstrual } \\
\text { syndrome }\end{array}$ & Dysmenorrhoea & $\begin{array}{l}\text { Premenstrual } \\
\text { syndrome }\end{array}$ & Dysmenorrhoea \\
\hline Present study & Significant & Significant & Not significant & Significant & Significant & Significant \\
\hline Rupavani et $\mathrm{al}^{29}$ & Significant & Not significant & Significant & Not significant & Significant & Not significant \\
\hline Lakshmi et al $^{30}$ & Significant & Not significant & Significant & Not significant & Significant & Not significant \\
\hline Sujatha et $\mathrm{al}^{15}$ & Significant & Not significant & Significant & Not significant & Significant & Not significant \\
\hline
\end{tabular}

Whereas, Nirmala et al reported a significant association between dysmenorrhoea and premenstrual syndrome with frequent consumption of junk food. Fujiwara et al found an association between fast food consumption and dysmenorrhoea. Significant association was observed with lack of physical exercise and premenstrual syndrome and dysmenorrhoea in present study. ${ }^{10,31}$ While in Rupavani et al, Anandha lakshmi et al and Sujatha et al studies, premenstrual symptoms were significant with lack of physical exercise, but not dysmenorrhoea. ${ }^{15,29,30}$

The limitation of present study is that data was collected from the single centre especially from one medical college participating students, and this may not represent to the general population of women. In addition, the data was recorded from the past memory at the time of filling the questionnaire, which might have a chance of recall bias.

\section{CONCLUSION}

In conclusion premenstrual symptoms, dysmenorrhoea and menstrual irregularities were more prevalent among young females. Majority of symptoms were stress, pain abdomen, irritability, backache, nausea and vomiting. Those who have experienced severe dysmenorrhoea, premenstrual symptoms, and menstrual irregularities showed limitation of working ability and college absenteeism. In this present study menstrual disorders were significantly associated with increase in BMI, consumption of junk food and lack of physical exercise. Early identification and interventions can resolve the menstrual disorders. Comprehensive education programs on lifestyle modifications like regular physical activities, promoting healthy eating habits should be emphasised to prevent menstrual abnormalities of young students as early as at school level. Therefore, further studies are required with a multicentre large sample size setting.

Funding: No funding sources

Conflict of interest: None declared

Ethical approval: The study was approved by the Institutional Ethics Committee

\section{REFERENCES}

1. Fraser IS, Critchley HO, Munro MG, Broder M: Can we achieve international agreement on terminologies and definitions used to describe abnormalities of menstrual bleeding? Hum Reprod, 2007;22(3):63543.

2. Braverman PK. Premenstrual syndrome and premenstrual dysphoric disorder. J Pediatr Adolesc Gynecol, 2007;20(1):3-12.

3. Cakir M, Mungan I, Karakas T, Girisken I, Okten A. Menstrual pattern and common menstrual disorders among university students in Turkey. Pediatr Int. 2007;49(6):938-42.

4. ACOG Committee on Adolescent Health Care: Menstruation in girls and adolescents using the menstrual cycle as a vital sign. Obstet Gynecol. 2006;108(5):1323-8.

5. Lakshmi SA. Impact of Life Style and Dietary Habits on Menstrual Cycle of College Students. Int journal of science and res, 2015;4(4):2845-7.

6. Kanchan Y, Rizwana S, Charu S, Kalpna G, Jitendra J, Goury C. Menstrual pattern in medical students 
and their knowledge and attitude towards it. Int Journ of Medand Health Res, 2018; 4(6):19-22.

7. Rowland AS, Baird DD, Long S, Wegienka G, Harlow SD, Alavanja M, Sandler DP. Influence of medical conditions and lifestyle factors on the menstrual cycle. Epidemiol. 2002;13(6):668-74.

8. Mohite RV, Mohite VR; Correlates of the menstrual problems among rural college students of Satara district. AI Ameen J Med Sci. 2013;6(3):213-8.

9. Narayan KA, Srinivasa DK, Pelto PJ,Veerammal S; Puberty rituals, reproductive knowledge and health of adolesecent schoolgirls in South India. Asia Pacific Population J. 2001;16(2):225-38.

10. Nirmala J L, Jayavani R.L, Nivedhana A P, Padma A, Vanajakshi N. A Study of Menstrual Disorders in Medical students and its correlation with Biological Variables. Sch J App Med Sci. 2014;2(6E):3165-75.

11. Singh A, Kiran D, Singh H, Nel B, Singh P, Tiwari P; Prevalence and severity of dysmenorrohea: A problem related to menstruation among first and second year female medical students. Indian J Physiol Pharmacol. 2008;52(4):389-97.

12. Shrotriya C, Amita R, Sujoy R, George AT. Menstrual characteristics and prevalence and effects of dysmenorrhea on quality of life of medical students. Intl $\mathbf{J}$ of Coll Res Int Med Public Health. 2012;4(4):275-94.

13. Rigon F, De Sanctis V, Bernasconi S, Bianchin L, Bona $\mathrm{G}$, Bozzola $\mathrm{M}$ et al.; Menstrual pattern and menstrual disorders among adolescents: an update of the Italian data. Ital J Pediatrics, 2012;38(1):38-46.

14. Begum J, Hossain AM, Nazneen SA. Menstrual pattern and common menstrual disorders among students in Dinajpur Medical College. Dinajpur Med Col J. 2009;2(2):37-43.

15. Sujatha V, Revathi M, Sujatha $C$ and Helena RajaKumari j. Evaluation Of Menstrual Disorders In First Year Female Medical And Dental Students. Int J Recent Sci Res. 2015;6(7):5066-9.

16. Rapkin AJ, Winer SA. Premenstrual syndrome and premenstrual dysphoric disorder: quality of life and burden of illness. Expert Rev Pharmacoecon Outcomes Res. 2009;9(2):157-70.

17. Wasnik VR, Dhumale D, Jawarkar AK. A study of the menstrual pattern and problems among rural school going adolescent girls of Amravati district of Maharashtra, India. Int $\mathbf{J}$ Res Med Sci. 2015;33(55):1252-6.

18. Kavitha C, Jamuna BL; A study of menstrual distress questionnaire in first year medical students. Int J Biol Med Res. 2013;4(2):3192-5.

19. Fujiwara T. Skipping breakfast is associated with dysmenorrhea in young women in Japan. Int $\mathbf{J}$ Food Sci Nutri. 2003;54(6):505-9.
20. Montero P, Bernis C, Loukid M, Hilali K, Baali A. Characteristics of menstrual cycles in Moroccan girls: prevalence of dysfunctions and associated behaviours. Ann Human Biol. 1999;26(3):243-9.

21. Nair P, Grover VL, Kannan AT. Awareness and practices of menstruation and pubertal changes amongst unmarried female adolescents in a rural area of East Delhi. Indian $\mathbf{J}$ Community Med. 2007;32(2):156.

22. Sheila W, Malathy K, Premila S. Menstrual and gynecological disorders in 500 school girls in Madras city. J Obstet Gynecol India. 1993;43:940-5.

23. Agarwal AK, Agarwal A. A study of dysmenorrhea during menstruation in adolescent girls. Indian $\mathrm{J}$ Community Med. 2010;35(1):159-64.

24. Satish Kumar PK, Shashikala C K, Suraj S K A Clinical Study of Menstrual Disturbances in Female Medical Students. Global J Res Analysis. 2016;5(12):4-6.

25. Nisreen Aref, Farzana Rizwan and M. Mustafa Abbas World J Med Sci. 2015;12 (2):109-14.

26. Sood M, Devi A, Azlinawati, Daher AM, Razali S, Nawawi H et al.; Poor correlation of stress levels and menstrual patterns among medical students. J Asian Behaviour Stud. 2012;2(7):59-66.

27. Houston AM, Abraham A, Huang Z, D'Angelo LJ. Knowledge, attitudes, and consequences of menstrual health in urban adolescent females. Journal of Pediatric and Adolescent Gynecology. 2006;19(4):271-5.

28. Bitzer J, Tschudin S, Stadlmayr W. Menstruation and its impact on women's health. Zentralblatt fur Gynakologie. 2005;127(5):282-7.

29. Rupavani K, Veena KS, Sabitha L, Hemanth Kumar VR, Bupathy A; Menstrual abnormalities in school going girls- are they related to dietary and exercise pattern? J Clin Diagn Res. 2013;7(11):2537-40.

30. Lakshmi AS, Priy M, Saraswathi I, Saravana A, Ramachandran C. Prevalence of Premenstrual syndrome and Dysmenorrhea among Female Medical students and its Association with college Absenteeism, Int J.Biol Med Res. 2011;2(4):1011-6.

31. Fujiwara T, Sato N, Awaji H, Sakamata HR. Nakata. Skipping breakfast adversely affects menstrual disorders in young college students. Int $\mathbf{J}$ Food Sci Nutr. 2009;60(6):23-31.

Cite this article as: Sreelakshmi U, Bindu VT, Subhashini T, Saritha K. Impact of dietary and lifestyle choices on menstrual patterns in medical students. Int J Reprod Contracept Obstet Gynecol 2019:8:1271-6. 